\title{
Characterization of a Variant of Xanthomonas citri subsp. citri that Triggers a Host-Specific Defense Response
}

\author{
María A. Chiesa, María F. Siciliano, Leonardo Ornella, Roxana A. Roeschlin, María A. Favaro, Natalia Pino Delgado, \\ Lorena N. Sendín, Ingrid G. Orce, L. Daniel Ploper, Adrian A. Vojnov, José Gadea Vacas, María P. Filippone, \\ Atilio P. Castagnaro, and María R. Marano
}

First, second, fourth, fifth, sixth, and fourteenth authors: Instituto de Biología Molecular y Celular de Rosario (IBR)-Consejo Nacional de Investigaciones Científicas y Tecnológicas (CONICET), Área Virología, Facultad de Ciencias Bioquímicas y Farmacéuticas, Universidad Nacional de Rosario, Suipacha 590, S2002LRK Rosario, Argentina; third author: Centro Internacional Franco Argentino de Ciencias de la Información y de Sistemas (CIFASIS), Blvd. 27 de Febrero 201 bis, S2000EZP Rosario, Argentina; seventh, eighth, ninth, twelfth, and thirteenth authors: Instituto de Tecnología Agroindustrial del Noroeste Argentino (ITA-NOA), Estación Experimental Agroindustrial Obispo Colombres (EEAOC)-CONICET, Av. William Cross 3150, Las Talitas T4101XAC Tucumán, Argentina; tenth author: Instituto de Ciencia y Tecnología Dr. Cesar Milstein, Fundación Pablo Cassará-CONICET, Saladillo 2468, C1440FFX Ciudad de Buenos Aires, Argentina; and eleventh author: Instituto de Biología Molecular y Celular de Plantas (IBMCP), Universidad Politécnica de ValenciaC.S.I.C, Ingeniero Fausto Elio, s/n. 46022 Valencia, España.

Accepted for publication 17 December 2012.

\begin{abstract}
Chiesa, M. A., Siciliano, M. F., Ornella, L., Roeschlin, R. A., Favaro, M. A., Delgado, N. P., Sendín, L. N., Orce, I. G., Ploper, L. D., Vojnov, A. A., Vacas, J. G., Filippone, M. P., Castagnaro, A. P., and Marano, M. R. 2013. Characterization of a variant of Xanthomonas citri subsp. citri that triggers a host-specific defense response. Phytopathology 103:555-564.

Citrus is an economically important fruit crop that is severely afflicted by Asiatic citrus bacterial canker (CBC), a disease caused by the phytopathogen Xanthomonas citri subsp. citri (X. citri). To gain insight into the molecular epidemiology of CBC, 42 Xanthomonas isolates were collected from a range of Citrus spp. across 17 different orchards in Tucumán,

phisms based on repetitive elements-based polymerase chain reaction showed that all 42 isolates belonged to $X$. citri. Interestingly, pathogenicity tests showed that one isolate, which shares $>90 \%$ genetic similarity to the reference strain $X$. citri $\mathrm{T}$, has host range specificity. This new variant of $X$. citri subsp. citri, named $X$. citri $\mathrm{A}^{\mathrm{T}}$, which is deficient in xanthan production, induces an atypical, noncankerous chlorotic phenotype in Citrus limon and C. paradisi and weak cankerous lesions in C. aurantifolia and C. clementina leaves. In C. limon, suppression of canker development is concomitant with an oxidative burst; xanthan is not implicated in the phenotype induced by this interaction, suggesting that other bacterial factors would be involved in triggering the defense response.
\end{abstract} Argentina and subjected to molecular, biochemical, and pathogenicity tests. Analysis of genome-specific X. citri markers and DNA polymor-

Argentina is one of the world's largest lemon producers, with an annual output of $\approx 1.2$ million tons according to the United States Department of Agriculture (http://www.fas.usda.gov/psd online/psdHome.aspx). A high percentage (88\%) of Citrus limon (lemon) trees are grown in the Tucumán province in the northwestern region of the country. Other Citrus spp., such as $C$. paradisi (grapefruit), C. sinensis (sweet orange), and C. clementina (mandarin), are also produced in Tucumán but on a lesser scale than $C$. limon.

Citrus bacterial canker (CBC) is a disease that seriously affects most commercially important Citrus spp. (16). It is caused by strains of two phylogenetically different and recently renamed groups of Xanthomonas: Xanthomonas citri subsp. citri strain A (Asiatic origin, $X$. citri) and $X$. fuscans subsp. aurantifolii $(X$. aurantifolii) strains B and C $(33,34)$. $X$. citri has the widest host range and is found throughout the world. X. aurantifolii $\mathrm{B}$, although it shares the same citrus hosts, is less virulent than $X$. citri. In contrast, $X$. aurantifolii $\mathrm{C}$ only induces canker symptoms on $C$. aurantifolia and is restricted to South America $(7,16)$.

Corresponding authors: M. R. Marano; E-mail address: marano@ibr-conicet.gov.ar A. P. Castagnaro; E-mail address: atilio@eeaoc.org.ar

http://dx.doi.org/10.1094/PHYTO-11-12-0287-R

This article is in the public domain and not copyrightable. It may be freely reprinted with customary crediting of the source. The American Phytopathological Society, 2013.
Additional keywords: genetic diversity, rep-PCR fingerprinting.

In Argentina, the Asiatic citrus canker appeared for the first time in 1975, became endemic in the northeast region around 1990, and has been confined there until March 2002, when the first outbreak of infection in the northwest region was declared $(7,39)$. In contrast, $X$. aurantifolii $\mathrm{B}$ is geographically restricted to South America and was originally identified on a few lemon orchards in 1927 in the northeast of Argentina. However, after the introduction of $X$. citri in Argentina, the $X$. aurantifolii B strain could not be isolated from the field (7).

The availability of the complete genome sequence and annotations of the CBC causal agent, X. citri strain 306 (12), have substantially improved the understanding of the genomic basis of the disease $(5,22,24)$. Moreover, these sequences have facilitated the development of molecular markers well suited for a quick and reliable detection of the pathogen in citrus orchards $(11,28)$.

In this work, we have characterized a collection of 42 Xanthomonas bacterial strains isolated from different Citrus spp. and geographic areas of the Tucumán province. Molecular analysis using the plasmid-borne $p t h A$ gene, a well-known pathogenicity determinant of CBC-causing Xanthomonas spp. $(1,35,40,41)$, showed that all field isolates contain $p t h \mathrm{~A}$ alleles or homologs. The analysis of two $X$. citri genome-specific markers $(11,12)$ revealed that all the isolates belonged to X. citri. Cluster analysis of genomic fingerprinting data showed low genetic diversity between the $X$. citri isolates from Tucumán and the $X$. citri reference strains. However, the pathogenicity tests on several citrus hosts 
have shown different levels of virulence and allowed the identification of a new variant of $X$. citri subsp. citri, named $X$. citri $\mathrm{A}^{\mathrm{T}}$. This new strain, which is deficient in xanthan production, triggers a host-specific suppression of canker development in $C$. limon, independently of the supplementation with exogenous xanthan. The $C$. limon- $X$. citri $\mathrm{A}^{\mathrm{T}}$ interaction led to an increased production of hydrogen peroxide $\left(\mathrm{H}_{2} \mathrm{O}_{2}\right)$, an early defense marker associated with resistance in citrus and citrus-related plants $(9,13,19)$.

This work supports the importance of diversity and pathogenicity analysis of pathogen collections from different citrusproducing areas in order to identify new $X$. citri variants of interesting behavior. Considering that most of the world's commercial citrus cultivars are moderately to highly susceptible to $X$. citri, the characterization of the molecular mechanisms involved in the interaction $C$. limon-X. citri $\mathrm{A}^{\mathrm{T}}$ would contribute to the understanding of the innate defense system of the plant and also the pathogenesis of $X$. citri.

\section{MATERIALS AND METHODS}

Bacterial strains, culture media, and growth conditions. In total, 44 Xanthomonas isolates were obtained from cankerous lesions of infected citrus trees grown in orchards from 17 areas in Tucumán, Argentina. Samples were collected from 2004 to 2007 during spring and summer months (Table 1). The geographic areas were strategically selected based on their importance in the citrus production of the region. One canker lesion was chosen from each sample for bacterial isolation. The colony was picked with a sterile needle and streaked onto plates of peptone-yeast extract-malt extract (PYM) medium (6), supplemented with D-glucose at a final concentration of $1 \%(\mathrm{wt} / \mathrm{vol})$ and $1.7 \%$ agar (wt/vol). This medium is suitable for the growth of both groups of canker-forming Xanthomonas spp. (24,37). Plates were incubated at $28^{\circ} \mathrm{C}$ for $72 \mathrm{~h}$. Yellow-colored colonies, convex in shape and shiny and mucoid in appearance (the typical phenotypic characteristics of Xanthomonas spp. colonies), were picked up again and streaked separately on PYM agar plates to purify each strain. All isolates, except $X$. citri T10 and T25, could be purified; consequently, 42 Xanthomonas isolates were characterized in this study (Table 1). The Xanthomonas reference strains used in this work are listed in Table 2 . These bacteria were also cultured at $28^{\circ} \mathrm{C}$ in PYM medium supplemented with D-glucose at a final concentration of $1 \%(\mathrm{wt} / \mathrm{vol})$ and $1.7 \%$ agar $(\mathrm{wt} / \mathrm{vol})$. Each new bacterial isolate was preserved in $20 \%$ (wt/vol) glycerol at $-80^{\circ} \mathrm{C}(32)$.

TABLE 1. Xanthomonas citri subsp. citri strains characterized in this study ${ }^{\mathrm{a}}$

\begin{tabular}{|c|c|c|c|c|c|c|}
\hline \multirow[b]{2}{*}{ Isolate } & \multirow[b]{2}{*}{ Host } & \multirow[b]{2}{*}{ Tissue } & \multirow[b]{2}{*}{ Origin $^{b}$} & \multirow[b]{2}{*}{ Year } & \multicolumn{2}{|c|}{ Pathogenicity tests ${ }^{c}$} \\
\hline & & & & & Citrus paradisi & C. limon \\
\hline X. citri $\mathrm{T} 1$ & C. limon & Fruit & Cruz Alta & 2004 & +++ & +++ \\
\hline X. citri $\mathrm{T} 2$ & C. limon & Leaf & Cruz Alta & 2004 & +++ & +++ \\
\hline X. citri T3 & C. limon & Stem & Cruz Alta & 2004 & +++ & +++ \\
\hline X. citri $\mathrm{T} 4$ & C. limon & Fruit & Cruz Alta & 2004 & +++ & ++ \\
\hline X. citri $\mathrm{T} 5$ & C. limon & Leaf & Yerba Buena & 2004 & +++ & ++ \\
\hline X. citri T6 & C. clementina & Leaf & Simoca & 2004 & +++ & +++ \\
\hline X. citri $\mathrm{T} 7$ & C. limon & Leaf & Tafí Viejo & 2004 & +++ & +++ \\
\hline X. citri $\mathrm{T} 8$ & C. limon & Stem & Burruyacu & 2004 & +++ & +++ \\
\hline X. citri T9 & C. sinensis & Leaf & Burruyacu & 2004 & +++ & +++ \\
\hline$X$. citri $\mathrm{T} 11$ & C. limon & Leaf & Lules & 2004 & ++ & ++ \\
\hline X. citri $\mathrm{T} 12$ & C. limon & Stem & Cruz Alta & 2005 & +++ & +++ \\
\hline X. citri $\mathrm{T} 13$ & C. limon & Leaf & Cruz Alta & 2005 & +++ & +++ \\
\hline X. citri T14 & C. limon & Fruit & Cruz Alta & 2005 & +++ & +++ \\
\hline$X$. citri $\mathrm{T} 15$ & C. clementina & Fruit & Monteros & 2005 & +++ & +++ \\
\hline X. citri $\mathrm{T} 16$ & C. limon & Leaf & Cruz Alta & 2005 & +++ & +++ \\
\hline$X$. citri $\mathrm{T} 17$ & C. limon & Fruit & Lules & 2005 & +++ & +++ \\
\hline X. citri T18 & C. limon & Stem & Cruz Alta & 2005 & +++ & +++ \\
\hline X. citri $\mathrm{T} 19$ & C. limon & Fruit & Cruz Alta & 2005 & +++ & +++ \\
\hline$X$. citri $\mathrm{T} 20$ & C. limon & Leaf & Cruz Alta & 2005 & +++ & +++ \\
\hline$X$. citri $\mathrm{T} 21$ & C. sinensis & Fruit & Famaillá & 2005 & +++ & +++ \\
\hline$X$. citri $\mathrm{T} 22$ & C. sinensis & Stem & Río Chico & 2006 & +++ & +++ \\
\hline$X$. citri $\mathrm{T} 23$ & C. limon & Stem & Tafí Viejo & 2006 & +++ & +++ \\
\hline$X$. citri $\mathrm{T} 24$ & C. sinensis & Fruit & Chicligasta & 2006 & +++ & +++ \\
\hline X. citri T26 & C. limon & Fruit & Tafí Viejo & 2006 & +++ & +++ \\
\hline$X$. citri T27 & C. limon & Fruit & Cruz Alta & 2006 & +++ & +++ \\
\hline$X$. citri $\mathrm{T} 28$ & C. limon & Fruit & Cruz Alta & 2006 & +++ & +++ \\
\hline$X$. citri $\mathrm{T} 29$ & C. paradisi & Fruit & Tafí Viejo & 2006 & +++ & +++ \\
\hline X. citri $\mathrm{T} 30$ & C. paradisi & Leaf & Tafí Viejo & 2006 & +++ & +++ \\
\hline$X$. citri $\mathrm{T} 31$ & C. limon & Stem & Tafí Viejo & 2006 & +++ & +++ \\
\hline X. citri $\mathrm{T} 32$ & C. paradisi & Stem & Tafí Viejo & 2006 & +++ & +++ \\
\hline X. citri $\mathrm{T} 33$ & C. paradisi & Fruit & Burruyacu & 2006 & +++ & +++ \\
\hline$X$. citri T34 & C. limon & Stem & Yerba Buena & 2006 & +++ & +++ \\
\hline X. citri $\mathrm{T} 35$ & C. limon & Fruit & Yerba Buena & 2007 & +++ & +++ \\
\hline X. citri T36 & C. clementina & Leaf & Chicligasta & 2007 & +++ & +++ \\
\hline X. citri $\mathrm{T} 37$ & C. paradisi & Leaf & Famaillá & 2007 & +++ & +++ \\
\hline X. citri T38 & C. limon & Stem & Tafí Viejo & 2007 & +++ & +++ \\
\hline X. citri T39 & C. sinensis & Fruit & Burruyacu & 2007 & +++ & +++ \\
\hline$X$. citri $\mathrm{T} 40$ & C. limon & Leaf & La Cocha & 2007 & +++ & +++ \\
\hline$X$. citri $\mathrm{T} 41$ & C. paradisi & Leaf & Cruz Alta & 2007 & +++ & +++ \\
\hline$X$. citri $\mathrm{T} 42$ & C. sinensis & Stem & Cruz Alta & 2007 & +++ & +++ \\
\hline X. citri $\mathrm{T} 43$ & C. sinensis & Fruit & Cruz Alta & 2007 & +++ & +++ \\
\hline X. citri $\mathrm{A}^{\mathrm{T}}$ & C. clementina & Leaf & Monteros & 2007 & + & + \\
\hline
\end{tabular}

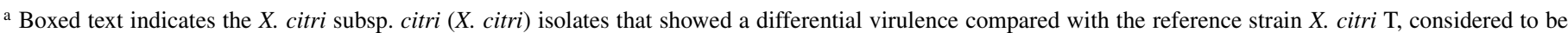
strongly virulent.

b Departments of Tucumán, Argentina.

c Strong canker (+++), weak canker $(++)$, and water-soaking or chlorosis (+). 
In vitro bacterial growth was carried out in PMY liquid medium supplemented with $1 \%$ (wt/vol) D-glucose and incubated at $28^{\circ} \mathrm{C}$ with shaking at $200 \mathrm{rpm}$. Overnight saturated cultures were diluted 1:100 in the same fresh medium and incubated at $28^{\circ} \mathrm{C}$. Aliquots of $200 \mu \mathrm{l}$ were taken in duplicate at 2-h intervals until $24 \mathrm{~h}$ and bacterial population was determined by measuring optical density (OD) at $600 \mathrm{~nm}$ in a spectrophotometer (Spectronic 20 Genesys; Thermo Electron Corporation, Boston).

Xanthan production. To measure xanthan production, strains were grown in PYM medium supplemented with $1 \%(\mathrm{wt} / \mathrm{vol})$ $\mathrm{D}$-glucose at $28^{\circ} \mathrm{C}$ for $24 \mathrm{~h}$ with shaking. Xanthan was precipitated from culture supernatants by ethanol, dried, and weighed as described by (43).

Nucleic acid purification. The molecular techniques used in this study were based on protocols previously described (32). Genomic DNA was isolated according to Chen et al. (10) with the following modifications: Xanthomonas strains were grown in MMXC minimal medium $\left(\mathrm{K}_{2} \mathrm{HPO}_{4}, 10.5 \mathrm{~g} /\right.$ liter; $\mathrm{KH}_{2} \mathrm{PO}_{4}, 4.5$ g/liter; $\left(\mathrm{NH}_{4}\right)_{2} \mathrm{SO}_{4}, 1 \mathrm{~g} /$ liter; sodium citrate, $0.5 \mathrm{~g} /$ liter; casein hydrolysate, $1.5 \mathrm{~g} /$ liter; and $1 \mathrm{mM} \mathrm{MgSO}_{4}$ ). Overnight-grown culture $(6 \mathrm{ml})$ was centrifuged for $5 \mathrm{~min}$ at $23,000 \times g$ and the pellet was vigorously suspended in $400 \mu \mathrm{l}$ of $40 \mathrm{mM}$ Tris-acetate (pH 7.8), $20 \mathrm{mM}$ sodium acetate, $1 \mathrm{mM}$ EDTA, and 1\% (vol/vol) sodium dodecyl sulfate. For RNA digestion, $60 \mu \mathrm{g}$ of DNase-free RNAse (Sigma Aldrich, St Louis) was used and the solution was incubated at $37^{\circ} \mathrm{C}$ for $1 \mathrm{~h}$. DNA was precipitated with $132 \mu \mathrm{l}$ of $5 \mathrm{M} \mathrm{NaCl}$ and the sample was centrifuged for $20 \mathrm{~min}$ at $18,000 \times g$. DNA was extracted twice with phenol/chloroform (1:1) and once with chloroform. Total DNA was collected by ethanol precipitation and resuspended in $30 \mu \mathrm{l}$ of sterile water. DNA samples were quantified spectrophotometrically (Spectronic 20 Genesys; Thermo Electron Corporation) and their quality was visualized under UV light after staining the $0.8 \%$ (wt/vol) agarose gel with ethidium bromide $(0.5 \mu \mathrm{g} / \mathrm{ml})$. The yields of genomic DNA were $\approx 500$ to $900 \mu \mathrm{g} / \mathrm{ml}$.

Polymerase chain reaction amplification and genomic fingerprinting. Primer pairs J-pth1 (5'-CTTCAACTCAAACG CCGGAC-3')/J-pth2 (5'-CATCGCGCTGTTCGGGAG-3') and JRXg (5'-GCGTTGAGGCTGAGACATG-3')/J-RXc2 (5'-CAAGT TGCCTCGGAGCTATC- $3^{\prime}$ ), designed based on the sequence of the nuclear localization signal motif of the pthA pathogenicity gene and the internal transcribed spacer (ITS) between the $16 \mathrm{~S}$ and $23 \mathrm{~S}$ genes of $X$. citri (11), respectively, were used to discriminate the Xanthomonas strains causing CBC. The polymerase chain reaction (PCR) conditions for the amplifications were performed according to Cubero et al. (11). Fragments of $556 \mathrm{bp}$ from the region encoding the $x p s D$ gene (AE012002), a component of the type II secretion system of the reference strain $X$. citri $306(2,12)$, were PCR amplified by using the primer pair F-xpsD (5'-ATTTCGTCCAGATGCGCTAC-3') and R-xpsD (5'-CTCGC GATTTTTGTTGGAAT- $3^{\prime}$ ). PCR reactions were performed in $25-\mu$ reaction mixtures containing $1 \times$ PCR buffer, $1.5 \mathrm{mM}$ $\mathrm{MgCl}_{2}, 0.5 \mu \mathrm{M}$ each primer, $0.2 \mathrm{mM}$ dNTPs, $1 \mathrm{U}$ of Taq DNA polymerase (Invitrogen, Carlsbad, CA), and $50 \mathrm{ng}$ of bacterial DNA as template. PCRs were performed with a Mastercycler
5333 (Eppendorf, Hamburg, Germany) by using the following conditions: 40 cycles of denaturation at $93^{\circ} \mathrm{C}$ for $30 \mathrm{~s}$, annealing at $60^{\circ} \mathrm{C}$ for $40 \mathrm{~s}$, and extension at $72^{\circ} \mathrm{C}$ for $45 \mathrm{~s}$; and finished with a single elongation step at $72^{\circ} \mathrm{C}$ for $10 \mathrm{~min}$. The PCR products were resolved on a $1 \%(\mathrm{wt} / \mathrm{vol})$ agarose gel stained with ethidium bromide $(0.5 \mu \mathrm{g} / \mathrm{ml})$.

Repetitive elements-based (rep)-PCR was conducted with three primer sets: (i) ERIC1R (5'-ATGTAAGCTCCTGGGGATTC AC-3')/ERIC2 (5'-AAGTAAGTGACTGGGGTGAGCG-3'), (ii) REP1R-I (5'-IIIICGICGICATCIGGC-3')/REP2-I (5'-ICGICTTA TCIGGCCTAC-3'), and (iii) primer BOXA1R (5'-CTACGGCA AGGCGACGCTGACG-3'), corresponding to repetitive extragenic palindromic (REP) sequences, enterobacterial repetitive intergenic consensus (ERIC), and the conserved repetitive BOX elements, respectively (21). The amplifications were performed on $50 \mathrm{ng}$ of purified genomic DNA in a $25-\mu \mathrm{l}$ reaction mixture, as described for BOX- and ERIC-PCR by Cubero et al. (11) and for REP-PCR by Louws et al. (20,21). The rep-PCR amplifications were performed with a Mastercycler 5333 (Eppendorf) using the following conditions (40 cycles): denaturation at $94^{\circ} \mathrm{C}$ for $30 \mathrm{~s}$, annealing at $53^{\circ} \mathrm{C}$ for $30 \mathrm{~s}$, and extension at $72^{\circ} \mathrm{C}$ for $90 \mathrm{~s}$. The exception was for REP-PCR, with $40^{\circ} \mathrm{C}$ as annealing temperature. All PCR reactions were started with an initial denaturation step at $94^{\circ} \mathrm{C}$ for $5 \mathrm{~min}$ and a single final extension cycle at $72^{\circ} \mathrm{C}$ for $10 \mathrm{~min}$. The ERICand REP-PCR amplification products were separated on a $2 \%$ $(\mathrm{wt} / \mathrm{vol})$ agarose gel and BOX-PCR products were separated on a $3 \%$ (wt/vol) agarose gel electrophoresis run at $110 \mathrm{~V}$ for $2 \mathrm{~h}$ in $1 \times$ Tris-acetate-EDTA buffer. DNA bands were visualized under UV light after staining the agarose gels with ethidium bromide $(0.5$ $\mu \mathrm{g} / \mathrm{ml})$. The agarose gels were photographed in a Molecular Imager ChemiDoc XRS ${ }^{+}$Imaging System (Bio-Rad Laboratories, Hercules, CA) by using the Quantity one software (Bio-Rad Laboratories). BOX-, ERIC-, and REP-PCR genomic fingerprints were reproduced from two independent DNA extractions for each bacterial strain and by two independent PCR reactions.

Genetic clustering analyses of the rep-PCR fingerprinting patterns. Gel-based rep-PCR fingerprinting patterns were used to compare the relatedness of the Xanthomonas isolates. Only the reproducible bands, regardless of intensity and ranging from 200 to 3,000 bp, were scored for each strain by using the Quantity one software (Bio-Rad Laboratories). The presence or absence of each band was converted into a binary matrix, scored as 1 for presence and 0 for absence. Data generated with the three sets of primers either individually or combined were analyzed using software NTSYS pc (version 2.01) (30). Genetic relationships among isolates were determined by Jaccard's similarity coefficient (17) followed by unweighted pair-group method using arithmetic averages (UPGMA) clustering analysis. The reliability of internal branches of the dendrogram was measured by bootstrap analysis with 2,000 replicates by using the Winboot software (45). Correlations between distance matrices were tested pairwise using the Mantel test (38) and all of them were performed using GENALEX 6 software (version 6.1), with 9,999 permutations (25).

Pathogenicity assays. 'Eureka' lemon (C. limon (L.) Burm. f.), 'Duncan' grapefruit (C. paradisi Macfad.), 'Clemenules' man-

TABLE 2. Xanthomonas reference strains used in this study

\begin{tabular}{|c|c|c|c|}
\hline Species & Strain & Origin & Reference \\
\hline \multirow[t]{4}{*}{ Xanthomonas citri subsp. citri $(X$. citri) } & $\mathrm{T}$ & Tucumán, Argentina & 28 \\
\hline & 2525 & New Zeeland & $\begin{array}{l}\text { Collection Française de Bactéries Phytopathogènes (CFBP) } \\
\text { INRA, Angers, France }\end{array}$ \\
\hline & 306 & Brazil & 12 \\
\hline & $99-1330$ & Argentina & $\begin{array}{l}\text { Instituto Nacional de Tecnología Agropecuaria INTA, } \\
\text { Bella Vista, Corrientes, Argentina }\end{array}$ \\
\hline \multirow[t]{2}{*}{ X. fuscans subsp. aurantifolii (X. aurantifolii) } & B-B832 & Argentina & 28 \\
\hline & C-1473 & Brazil & 28 \\
\hline$X$. campestris pv. campestris $(X$. campestris) & 8004 & $\ldots$ & 28 \\
\hline$X$. campestris pv. vesicatoria $(X$. vesicatoria) & $85-10$ & $\ldots$ & 28 \\
\hline
\end{tabular}


darin (C. clementina Tanaka), and Key or Mexican lime $(C$. aurantifolia (Christm.) Swingle) plants grafted on Troyer citrange (Poncirus trifoliata (L.) Raf. $\times$ C. sinensis (L.) Osb.) were grown in a greenhouse at a temperature of 20 to $25^{\circ} \mathrm{C}$ for 18 months. Bacterial suspensions were inoculated by pressure infiltration or spray methods on Citrus spp. young leaves (80 to $100 \%$ expansion) according to published methods (37). The bacterial concentrations were photometrically adjusted to $\approx 10^{7} \mathrm{CFU} / \mathrm{ml}$ in $10 \mathrm{mM}$ $\mathrm{MgCl}_{2}$ (i.e., an $\mathrm{OD}$ of 0.1 at $600 \mathrm{~nm}$ ). Inoculated plants were maintained in a growth cabinet, with temperatures of 25 to $28^{\circ} \mathrm{C}$, high humidity, and a photoperiod of $16 \mathrm{~h}$ of light, at an intensity of 150 to $200 \mu \mathrm{E} / \mathrm{s} / \mathrm{m}^{2}$. Inoculations involved a minimum of three leaves from each of three plants. As control of infection (without bacteria), $10 \mathrm{mM} \mathrm{MgCl}_{2}$ was used. Disease progression was monitored phenotypically in three separate biological assays over 2 weeks and the degree of virulence of each inoculated Xanthomonas strain was evaluated on different citrus host plants. Disease symptoms were classified as follows: strong canker $(+++)$, weak canker $(++)$, and water soaking or chlorosis $(+)$. The symptoms were registered by digital photographs and through analysis of bacterial population growth (29).

$\mathrm{H}_{2} \mathrm{O}_{2}$ detection. The intracellular $\mathrm{H}_{2} \mathrm{O}_{2}$ accumulation was analyzed by the oxidation of $2^{\prime}, 7^{\prime}$-dichlorfluorescein-diacetate (DCFH-DA) (Sigma-Aldrich), as described by Enrique et al. (13). Citrus leaves were vacuum-infiltrated with $5 \mu \mathrm{M}$ DCFH-DA and incubated in the dark for $30 \mathrm{~min}$. Subsequently, the treated samples were washed in phosphate-buffered saline and observed with a fluorescence microscope (BH2; Olympus Optical Ltd. Company, Tokyo). The experiment was repeated three times on at least three different plants, and three leaves per plant were examined.

\section{RESULTS}

Characterization of 42 new canker-forming Xanthomonas isolates. Morphological characteristics of the 42 Xanthomonas
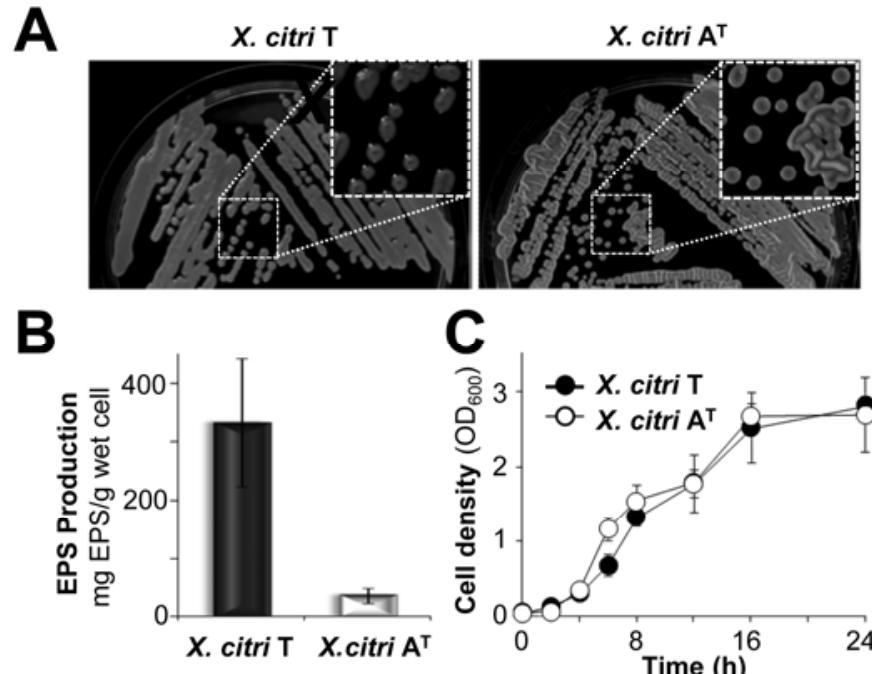

Fig. 1. Morphological characterization of Xanthomonas isolates. A, Xanthomonas citri subsp. citri $\left(X\right.$. citri) strains $\mathrm{T}$ and $\mathrm{A}^{\mathrm{T}}$ were grown at $28^{\circ} \mathrm{C}$ in peptone-yeast extract-malt extract (PYM) medium supplemented with $1 \%$ (wt/vol) D-glucose and $1.7 \%$ (wt/vol) agar plates. Bacterial colonies stored at $4^{\circ} \mathrm{C}$ for $>5$ days are shown enlarged in the top inset. B, Extracellular polysaccharide (EPS) production of $X$. citri strains grown in PYM medium supplemented with $1 \%(\mathrm{wt} / \mathrm{vol}) \mathrm{D}$-glucose. Bars represent the EPS yield, expressed in wet weight of cells. Values are means \pm standard deviation (SD) of three independent determinations. C, In vitro bacterial growth of $X$. citri strains $\mathrm{T}$ and $\mathrm{A}^{\mathrm{T}}$ in PYM medium supplemented with $1 \%$ (wt/vol) D-glucose. Values given are the means \pm SD of duplicate measurements from three independent experiment. isolates (Table 1) resembled those of the $X$. citri reference strains (Table 2), showing a slimy phenotype and convex and yellow colonies on PYM agar plates, supplemented with $1 \%(\mathrm{wt} / \mathrm{vol}) \mathrm{D}$ glucose. Only one isolate, hereafter named X. citri $\mathrm{A}^{\mathrm{T}}$, showed dull colonies with uneven and dry surfaces when the plates were stored at $4{ }^{\circ} \mathrm{C}$ for $>5$ days (Fig. 1A). This phenotype resembles xanthomonad mutants that are deficient in the production of xanthan, the major extracellular polysaccharide (EPS) secreted by Xanthomonas spp. $(18,29)$. Indeed, large differences in EPS production were observed between the reference strain $X$. citri $\mathrm{T}$ and the isolate $X$. citri $\mathrm{A}^{\mathrm{T}}$ after ethanol precipitation from the culture supernatant (Fig. 1B). The reference strain $X$. citri $\mathrm{T}$ produced $330 \pm 110 \mathrm{mg}$ EPS/g of wet cells, whereas $X$. citri $\mathrm{A}^{\mathrm{T}}$ produced $40 \pm 10 \mathrm{mg}$ EPS/g of wet cells. However, this isolate showed no loss of viability compared with $X$. citri $\mathrm{T}$ because both bacterial populations exhibited similar in vitro growth kinetics in PMY liquid medium supplemented with $1 \%$ (wt/vol) glucose (Fig. 1C).

In order to characterize the isolated canker-forming Xanthomonas spp., the well-known pathogenicity gene $p t h A$ was used as molecular marker for CBC diagnosis $(11,28)$. PCR amplification from total DNA of the 42 Xanthomonas isolates showed the presence of the pthA marker (Fig. 2A). As controls, all the CBCcausing Xanthomonas reference strains (X. citri T and 306 and $X$. aurantifolii $\mathrm{B}$ and $\mathrm{C}$ ) amplified the target sequence, with the exception of the non-host pathogen of citrus $X$. campestris strain 8004 (Fig. 2A).

Because $X$. aurantifolii strain B has not been isolated from the field since the introduction of $X$. citri (7), we could infer that the presence of the pthA marker is sufficient for CBC diagnosis. However, multiple copies of the pthA gene in the plasmids of a single Xanthomonas strain exist $(12,35)$ which allow inter- and intragenic recombinations, resulting in paralogs with altered

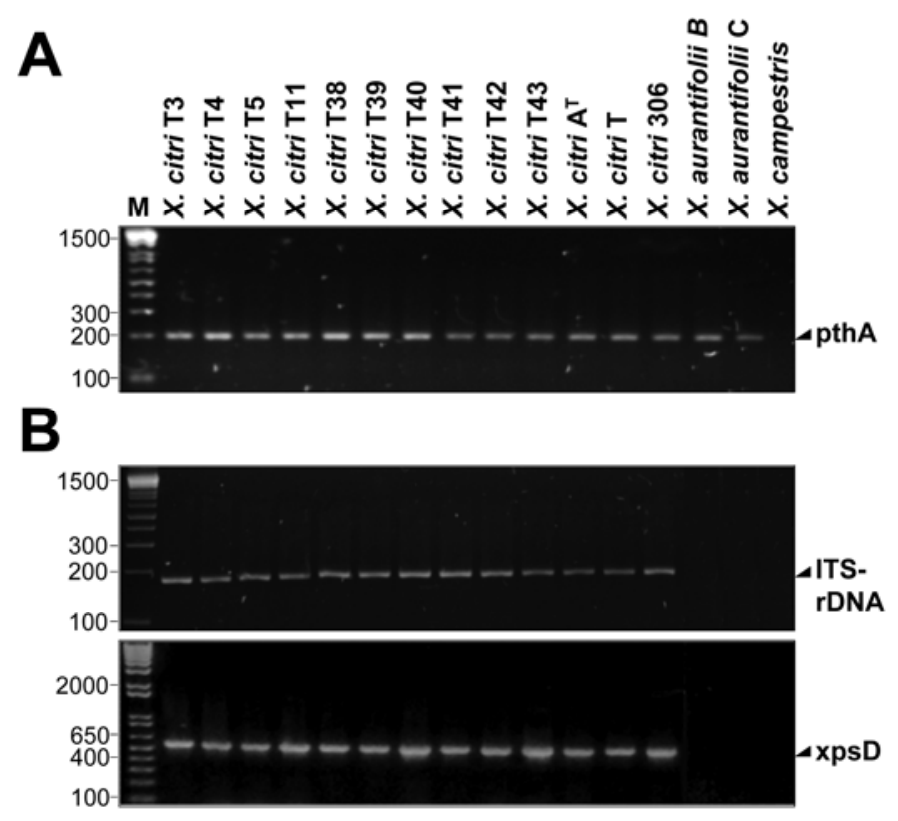

Fig. 2. Genotypic characterization of Xanthomonas isolates by specific molecular markers. Analysis of 11 representative isolates of Xanthomonas citri subsp. citri $\left(X\right.$. citri) (T3-5, T11, T38-43, and $\mathrm{A}^{\mathrm{T}}$ ) and 5 Xanthomonas reference strains: $X$. citri $\mathrm{T}$ and $306, X$. fuscans subsp. aurantifolii $(X$. aurantifolii) strains $\mathrm{B}$ and $\mathrm{C}$, and $X$. campestris pv. campestris (X. campestris) strain 8004, using A, citrus canker-specific plasmid pthA polymerase chain reaction $(\mathrm{PCR})$-based marker of approximately $200 \mathrm{bp}$ and $\mathbf{B}, X$. citri-specific genomic internal transcribed spacer rDNA and xpsD PCR-based markers of 179 and $560 \mathrm{bp}$, respectively. Resulting PCR products were subjected to $2 \%$ (wt/vol) agarose gel electrophoresis containing ethidium bromide at $0.5 \mu \mathrm{g} / \mathrm{ml}$. Arrows indicate the positions of the molecular markers. M: molecular size standards (1-kb Plus DNA Ladder; Invitrogen, Carlsbad, CA). 
pathogenicity or virulence phenotypes $(1,35,44)$. For this reason, the 42 isolates were analyzed with two $X$. citri genome-specific markers. One was based on the ITS region of the rDNA sequence of $X$. citri (11) and the other was designed based on the xpsD gene, a component of the type II secretion system $(2,12)$ and developed in this work. The expected molecular markers from the ITS and $x p s D$ sequences were present in all 42 Xanthomonas isolates and in the $X$. citri reference strains tested (Fig. 2B). These markers were absent when genomic DNA from the $X$. aurantifolii strains $\mathrm{B}$ and $\mathrm{C}$ and $X$. campestris 8004 reference strains were analyzed (Fig. 2B). These results demonstrated that the $42 \mathrm{CBC}$ causing Xanthomonas strains isolated from 17 areas within the Tucumán province of Argentina belong to $X$. citri, confirming the absence of $X$. aurantifolii $\mathrm{B}$ in this region.

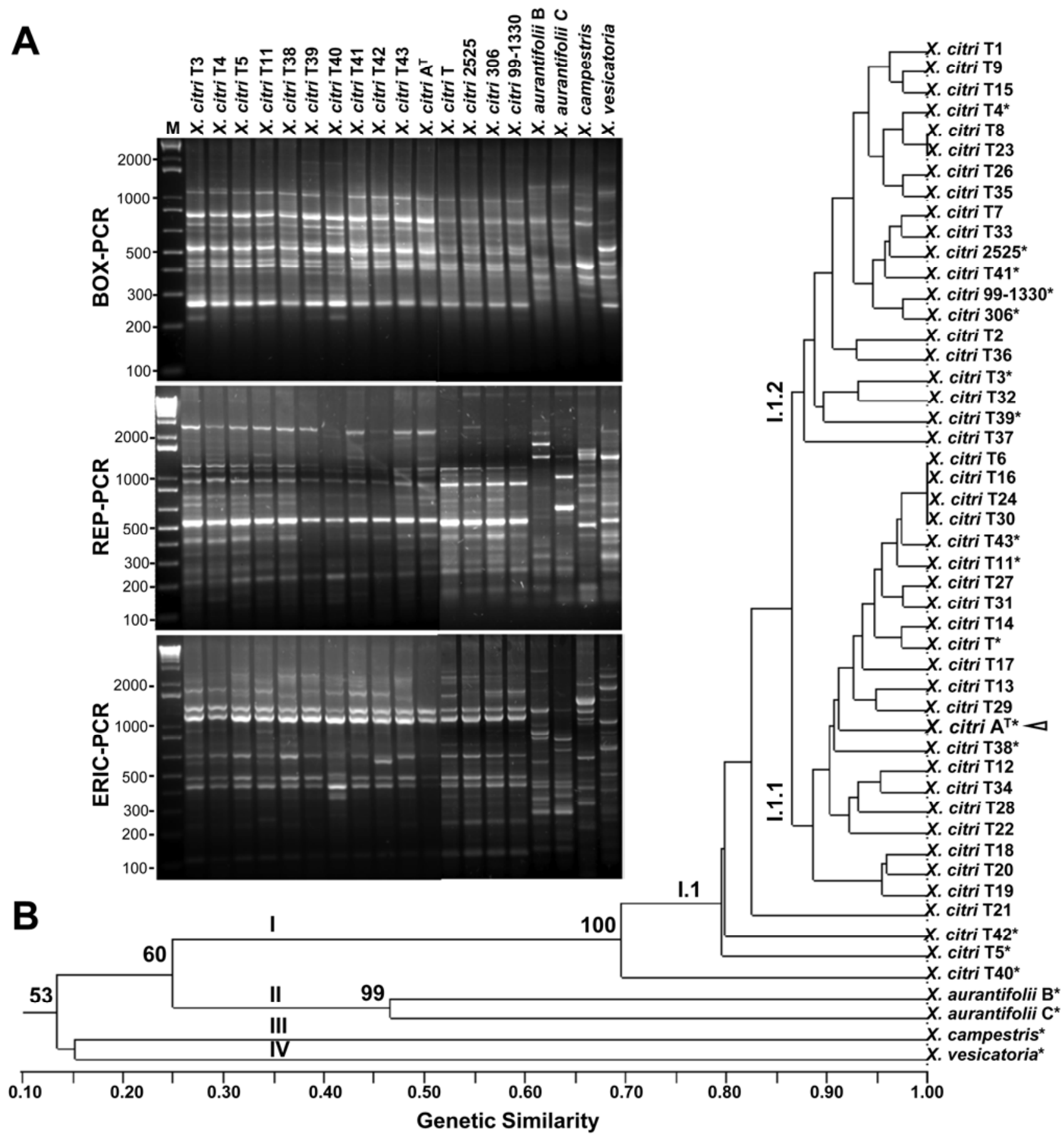

Fig. 3. Genotypic diversity analysis among Xanthomonas citri subsp. citri (X. citri) strains. A, Genomic fingerprinting of Xanthomonas strains generated by BOX, repetitive extragenic palindromic (REP), and enterobacterial repetitive intergenic consensus (ERIC) polymerase chain reaction (PCR) (repetitive elements-based [rep]-PCRs). Eleven representative $X$. citri isolates (T3-5, T11, T38-43, and $\mathrm{A}^{\mathrm{T}}$ ) and the reference strains $X$. citri $\mathrm{T}, 2525,306$, and 99-1330; X. fuscans subsp. aurantifolii (X. aurantifolii) strains B and C; X. campestris pv. campestris (X. campestris) strain 8004; and X. campestris pv. vesicatoria (X. vesicatoria) strain 85-10 are shown. Genomic profiles obtained by rep-PCR were separated by electrophoresis on agarose gels containing ethidium bromide at $0.5 \mu \mathrm{g} / \mathrm{ml}$. M: molecular size standards (1-kb Plus DNA Ladder; Invitrogen, Carlsbad, CA). B, Dendogram constructed by using the unweighted pair-group method using arithmetic averages-Jaccard algorithm and the combined rep-PCR fingerprinting data shows the genetic relationships of the $42 X$. citri isolates with respect to the reference strains $X$. citri T, 2525, 306, and 99-1330; X. aurantifolii B and C; X. campestris strain 8004; and X. vesicatoria strain 85-10. Numbers at the branch points represent the bootstrap values $(>50)$ obtained from 2,000 replicates. I to IV indicate major clusters referred in the text, * represents strains shown in A, and the open triangle notes the variant $X$. citri $\mathrm{A}^{\mathrm{T}}$. 
Genetic relationships among $X$. citri subsp. citri strains. repPCR markers have been useful for determining genetic relationships between Xanthomonas spp., including those species which are citrus pathogens $(11,15,23,27)$. In order to establish the genotypic variability and genetic relationships within the bacterial collection, rep-PCR genomic fingerprinting analysis was performed. BOX-, ERIC-, and REP-PCR (rep-PCR) were carried out from purified total DNA of the $42 \mathrm{X}$. citri strains and the Xanthomonas reference strains (Tables 1 and 2). The rep-PCR-amplified fragments generated complex genomic fingerprinting patterns with multiple and reproducible bands of distinct intensities. The average number of bands per strain varied from 13 to 16 for BOX- and REP-PCR and from 9 to 16 for ERIC-PCR. The molecular size of the bands was 200 to $1,650 \mathrm{bp}$ for BOX-PCR and 200 to 3,000 bp for REP- and ERIC-PCR. rep-PCR-generated profiles easily distinguished the $X$. citri strains from the other CBC-causing Xanthomonas bacteria belonging to $X$. aurantifolii strains B and C (Fig. 3A).

Based on the results of Mantel tests, the data derived from each individual rep-PCR typing technique were congruent $(P<0.0001)$, allowing the UPGMA-Jaccard clustering analysis from the three combined rep-PCR-generated fingerprinting data. This analysis discriminated the strains in four distinct clusters, from I to IV, consistent with the four main Xanthomonas groups: $X$. citri, $X$. aurantifolii strains B and C, X. campestris, and X. vesicatoria, respectively. The four clusters were clearly separated at $25 \%$ similarity, with bootstrap values $>50 \%$ (Fig. 3B). Cluster I contained all the $X$. citri strains with genomic similarity of 70 to

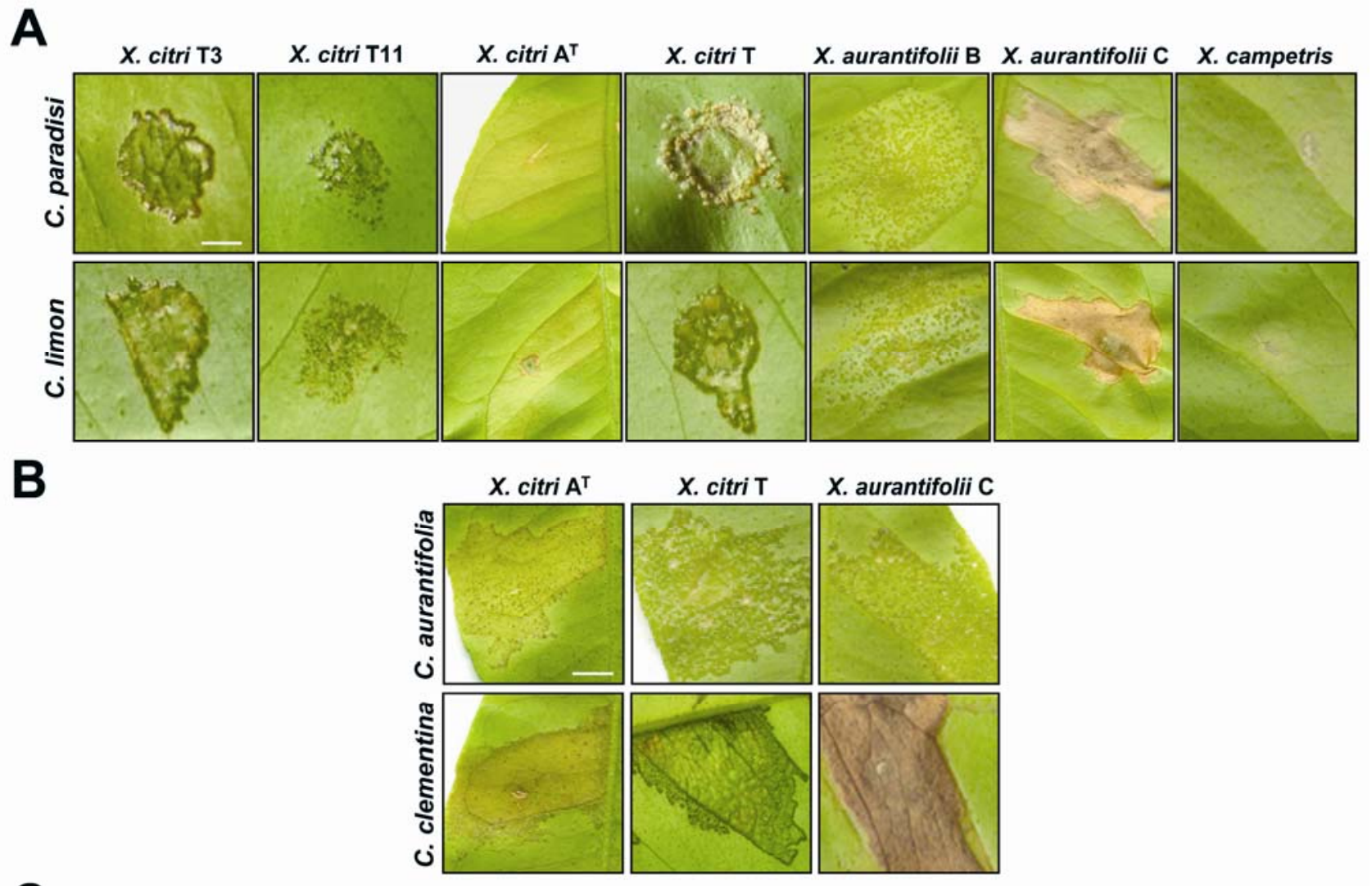

C

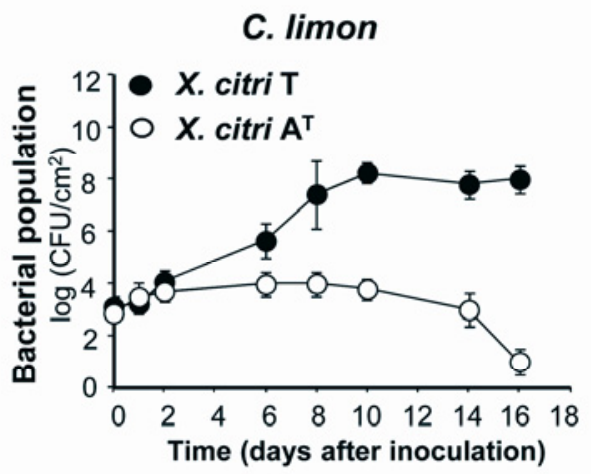

C. aurantifolia

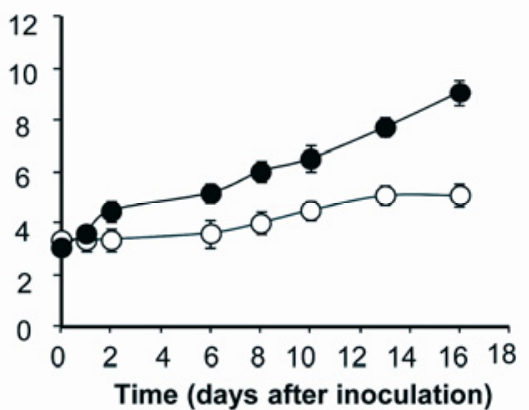

C. clementina

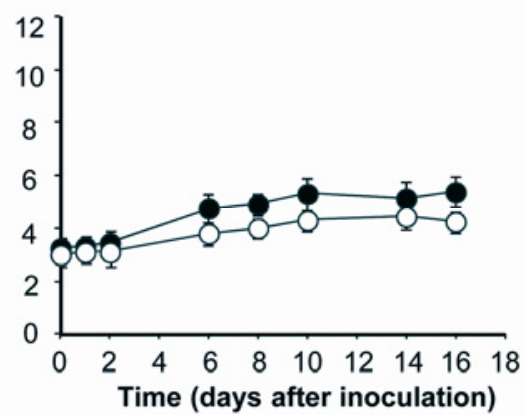

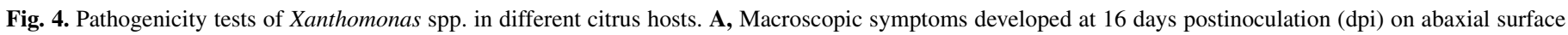

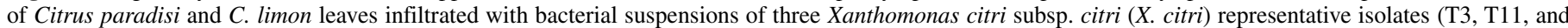

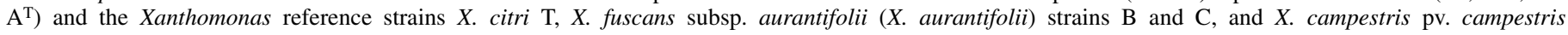

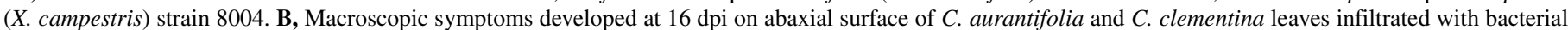

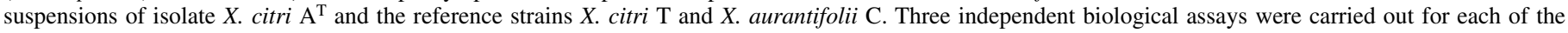

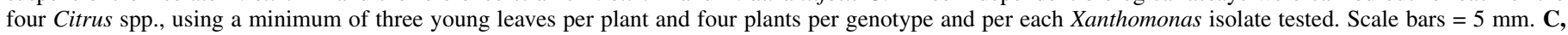

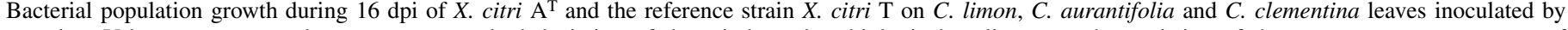

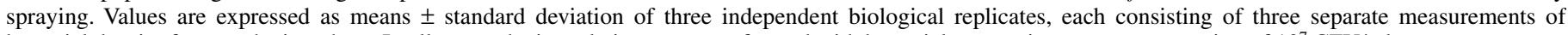
bacterial density from each citrus host. In all cases, the inoculations were performed with bacterial suspensions at a concentration of $10^{7} \mathrm{CFU} / \mathrm{ml}$. 
$100 \%$. Inside this cluster, some isolates $(X$. citri T40, T5, T21, and T42) were clearly discriminated with genetic similarity of 70 to $82 \%$. The rest of the $X$. citri strains were markedly separated into two major sub-subclusters (I.1.1 and I.1.2) with similarities $>85 \%$. Interestingly, the variant $X$. citri $\mathrm{A}^{\mathrm{T}}$ showed a genomic similarity $>90 \%$ related to the other $21 X$. citri strains and the reference strain $X$. citri T (Fig. 3B).

Host range specificity of a new $X$. citri subsp. citri isolate. The $42 X$. citri field isolates were evaluated for pathogenicity and virulence on two Citrus spp. that were chosen as indicators of high $(C$. paradisi) and moderate $(C$. limon) susceptibility to this pathogen, and to determine whether there were any differences in response to challenge infection between them (Table 1). Young leaves of both citrus hosts were inoculated with bacterial suspensions of each individual strain at $10^{7} \mathrm{CFU} / \mathrm{ml}$ by pressure infiltration (37) in order to obtain maximum response, and symptom development was monitored over a period of 16 days postinoculation (dpi).

In all, $X$. citri isolates were pathogenic in $C$. paradisi, inducing symptoms similar to those observed after inoculation of the reference strain $X$. citri $\mathrm{T}$. Most of them showed strong virulence $(+++)$ (Table 1), inducing typical CBC symptoms characterized by surface-penetrating necrotic lesions surrounded by oily, watersoaked margins and yellow chlorotic rings. $X$. citri T3 is shown as a representative for these strongly virulent isolates (Fig. 4A). Isolate $X$. citri T11 was an exception to the strong virulence observed, causing cankerous lesions significantly smaller in size and less numerous than those developed by the rest of the virulent isolates. These symptoms were more similar to those developed by $X$. aurantifolii B (Fig. 4A).

When tested for pathogenicity in C. limon, all X. citri isolates showed strong virulence in this host except for isolates $X$. citri T4, T5, and T11, which showed weaker symptoms (++) (Table 1; Fig. 4A).

In contrast to the above, the isolate $X$. citri $\mathrm{A}^{\mathrm{T}}$, which has reduced xanthan (Fig. 1B), induced atypical noncankerous chlorotic phenotype on both $C$. paradisi and $C$. limon at 5 dpi (+) (Table 1), which remained over the 16-dpi monitoring period (Fig. 4A). The type of lesion and time between the inoculation and its appearance seem to be related to a host-specific defense response. However, the symptoms phenotype was different from the canonical hypersensitive response (HR) induced by $X$. aurantifolii $\mathrm{C}$ at 4 to 5 dpi in both $C$. paradisi and $C$. limon leaves. Plants inoculated with $X$. campestris 8004, for which citrus is a non-host, showed no symptoms (Fig. 4A).

To further analyze the host range of the variant $X$. citri $\mathrm{A}^{\mathrm{T}}, C$. aurantifolia, which is the most susceptible host to CBC-causing Xanthomonas spp., was tested. Young leaves were inoculated with X. citri $\mathrm{A}^{\mathrm{T}}$ bacterial suspensions $\left(10^{7} \mathrm{CFU} / \mathrm{ml}\right)$ by pressure infiltration. Interestingly, the cankerous symptoms induced by $X$. citri $\mathrm{A}^{\mathrm{T}}$ in this host at 16 dpi were clearly weaker compared with those developed by the Xanthomonas reference strains (Fig. 4B). However, unlike in $C$. paradisi and $C$. limon, there was slight water soaking around the infiltration site. As control, the pathogenicity test in $C$. clementina, the host from which this strain was isolated, showed that $X$. citri $\mathrm{A}^{\mathrm{T}}$ induced cankerous lesions slightly weaker than the reference strain $X$. citri $\mathrm{T}$. In this citrus host, X. aurantifolii $\mathrm{C}$ induced a clear HR (Fig. 4B).

Bacterial populations of the isolate $X$. citri $\mathrm{A}^{\mathrm{T}}$ and the reference strain $X$. citri $\mathrm{T}$ were compared following inoculation of $C$. limon, C. aurantifolia, and $C$. clementina plants by spraying the bacterial suspensions $\left(10^{7} \mathrm{CFU} / \mathrm{ml}\right)$. No differences in growth kinetics were observed between the isolate $X$. citri $\mathrm{A}^{\mathrm{T}}$ and the reference strain $X$. citri T up to 2 dpi (Fig. 4C). However, after this period, substantial variations in the population of these bacteria were observed in each host. In $C$. limon leaves, the population of the isolate $X$. citri $\mathrm{A}^{\mathrm{T}}$ remained stable and, at $10 \mathrm{dpi}$, began to decline; no bacteria could be recovered after $16 \mathrm{dpi}$. These findings are in accordance with the suppression of canker development in this plant-pathogen interaction. In contrast, the population of the reference strain $X$. citri $\mathrm{T}$ increased by more than seven orders of magnitude over the same monitoring period (Fig. 4C). Similar growth profiles were seen for $X$. citri $\mathrm{A}^{\mathrm{T}}$ and the reference strain $X$. citri $\mathrm{T}$ in $C$. paradisi plants (data not shown). In C. aurantifolia leaves, population size of the isolate $X$. citri $\mathrm{A}^{\mathrm{T}}$ was three orders

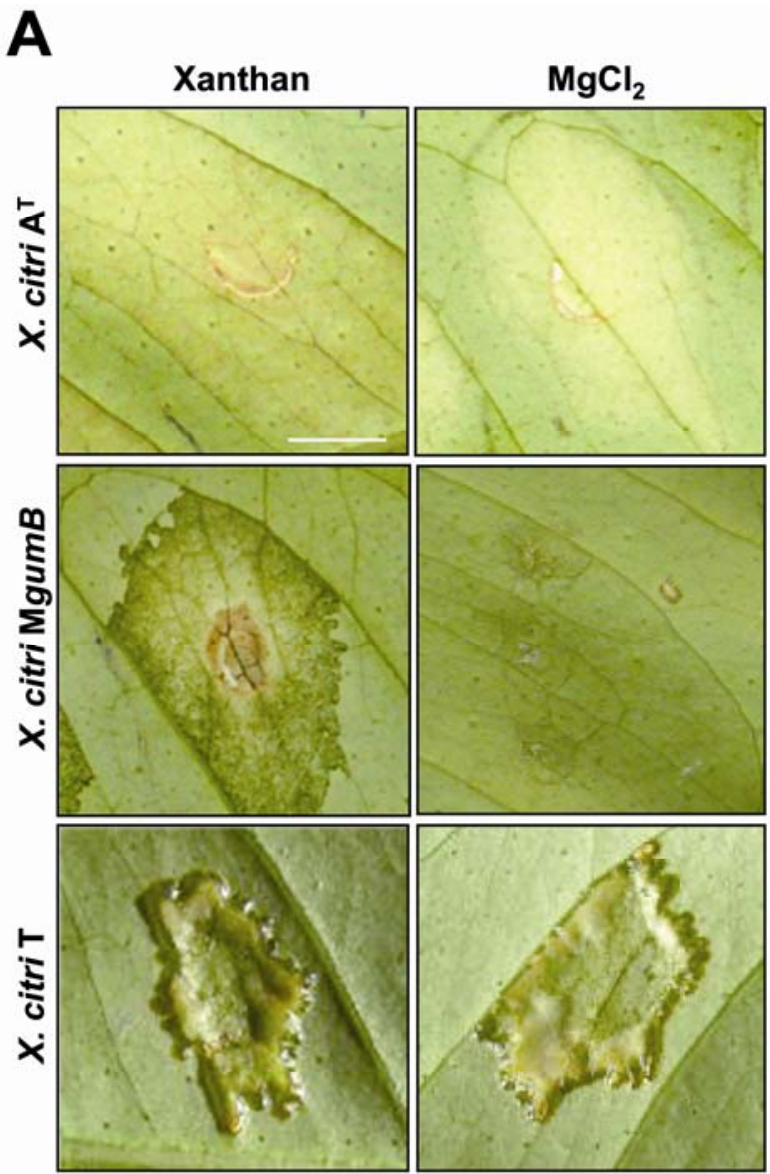

B

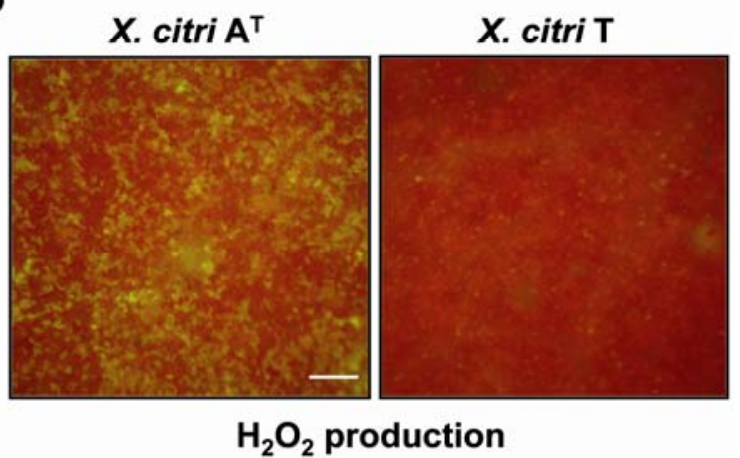

Fig. 5. Xanthomonas citri subsp. citri $\left(X\right.$. citri) strain $\mathrm{A}^{\mathrm{T}}$ triggers host defense response in Citrus limon. A, Symptoms on abaxial surface of $C$. limon leaves co-inoculated with either xanthan $(200 \mu \mathrm{g} / \mathrm{ml})$, produced by the reference strain $X$. citri $\mathrm{T}$, or $10 \mathrm{mM} \mathrm{MgCl}_{2}$; and bacterial suspensions $\left(10^{7} \mathrm{CFU} / \mathrm{ml}\right)$ of the strains $X$. citri $\mathrm{A}^{\mathrm{T}}$, the xanthan-deficient mutant $X$. citri $\mathrm{MgumB}$, and the reference strain $X$. citri T. Symptoms were evaluated at 16 days postinoculation (dpi). Three independent biological assays were carried out for each of the three bacterial strains using three young leaves from three $C$. limon plants. Scale bar $=5 \mathrm{~mm}$. B, Young $C$. limon leaves infiltrated with bacterial suspensions $\left(10^{7} \mathrm{CFU} / \mathrm{ml}\right)$ of isolate $X$. citri $\mathrm{A}^{\mathrm{T}}$ and reference strain $X$. citri $\mathrm{T}$ were stained with $2^{\prime}, 7^{\prime}$-dichlorfluorescein-diacetate (DCFH-DA) for analysis of $\mathrm{H}_{2} \mathrm{O}_{2}$ production at $5 \mathrm{dpi}$ and observed by fluorescence microscopy $(\times 100$ magnification). Scale bar $=100 \mu \mathrm{m}$. The experiment was repeated on at least three different plants, and three leaves per plant were examined. 
of magnitude lower than the $X$. citri T population (Fig. 4C). In contrast, assessment of the bacterial population in C. clementina plants revealed no differences between both $X$. citri strains (Fig. 4C). These results are consistent with the observation that $X$. citri $\mathrm{A}^{\mathrm{T}}$ produces canker symptoms on C. clementina plants (Fig. $4 \mathrm{~B}$ ).

$X$. citri subsp. citri strain $\mathrm{A}^{\mathrm{T}}$ triggers an xanthan-independent defense response in $C$. limon. Results indicated that the new variant $X$. citri $\mathrm{A}^{\mathrm{T}}$ induces a differential response depending on the inoculated Citrus spp., suggesting narrow host range specificity (Fig. 4).

Recently, we have shown that xanthan suppresses pathogenassociated molecular pattern (PAMP)-induced signaling in $C$. limon (13). X. citri $\mathrm{A}^{\mathrm{T}}$ produces almost 10 times less EPS than reference strain $X$. citri T (Fig. 1B). In order to determine whether the xanthan deficiency is involved in the noncankerous phenotype induced by $X$. citri $\mathrm{A}^{\mathrm{T}}$ in $C$. limon plants, we evaluated the capability of exogenous xanthan to restore the pathogenicity of $X$. citri $\mathrm{A}^{\mathrm{T}}$. Young $C$. limon leaves were inoculated with a mix of purified xanthan from the reference strain X. citri T $(200 \mu \mathrm{g} / \mathrm{ml})$ and a bacterial suspension of $X$. citri $\mathrm{A}^{\mathrm{T}}\left(10^{7} \mathrm{CFU} / \mathrm{ml}\right)$ by pressure infiltration. Remarkably, the response induced by the xanthandeficient $X$. citri $\mathrm{A}^{\mathrm{T}}$ in $C$. limon was maintained in the samples supplemented with xanthan at 16 dpi (Fig. 5A). However, similar xanthan treatment successfully restored the ability to develop canker symptoms of the nonpathogenic xanthan-defective mutant, $X$. citri MgumB (29). No differences in symptom development were observed when the reference strain $X$. citri $\mathrm{T}$ was inoculated with xanthan or $10 \mathrm{mM} \mathrm{MgCl}_{2}$ (Fig. 5A). These results demonstrated that the lower xanthan production of $X$. citri $\mathrm{A}^{\mathrm{T}}$ is not responsible for the suppression of canker development induced by this $X$. citri variant in $C$. limon.

To gain further insights into the host-specific response triggered against $X$. citri $\mathrm{A}^{\mathrm{T}}$, we analyzed the production of $\mathrm{H}_{2} \mathrm{O}_{2}$ as an early defense marker $(13,26)$ in $C$. limon plants. A substantial accumulation of $\mathrm{H}_{2} \mathrm{O}_{2}$ in leaves infiltrated with $X$. citri $\mathrm{A}^{\mathrm{T}}\left(10^{7}\right.$ $\mathrm{CFU} / \mathrm{ml}$ ) was observed at $3 \mathrm{~h}$ post inoculation and was maintained at a high level at 5 dpi. No $\mathrm{H}_{2} \mathrm{O}_{2}$ was observed in control leaves infiltrated with the reference strain $X$. citri T (Fig. 5B).

The $\mathrm{H}_{2} \mathrm{O}_{2}$ itself and the signaling triggered by this molecule are eventually able to contain the pathogen (26). Our findings suggest that the $\mathrm{H}_{2} \mathrm{O}_{2}$ accumulation would contribute to the inhibition of $X$. citri $\mathrm{A}^{\mathrm{T}}$ population growth in C. limon plants (Fig. 4C).

\section{DISCUSSION}

In this work, we characterized the genetic diversity and degree of virulence of a collection of 42 Xanthomonas strains isolated from cankerous lesions of a range of infected Citrus spp. from 17 areas within the Tucumán province in northwest Argentina. Molecular analysis using $X$. citri genome-specific markers showed that all 42 CBC-causing Xanthomonas strains belong to $X$. citri subsp. citri. In addition, reproducible rep-PCR genomic fingerprints were obtained for all $X$. citri field strains, collected in four different years (2004 to 2007) from different locations, tissue, and citrus hosts. The combined cluster analysis of the three rep-PCR fingerprinting data distinguished more haplotypes between the $X$. citri strains than individual analysis (data not shown), most of them with similarities from 80 to $100 \%$. This analysis did not show correlation with the severity of the symptoms developed by each $X$. citri isolate. Most of the isolates collected in Tucumán were pathogenically similar to the reference strain $X$. citri $\mathrm{T}$, eliciting typical CBC symptoms when inoculated on $C$. paradisi and $C$. limon leaves.

The high similarity detected between the isolates is correlated with previous data obtained with $X$. citri collections isolated from different geographical areas $(4,8,11)$. The low degree of global genetic diversity found in the $X$. citri population could be mainly due to commercial citrus cultivars (e.g., C. sinensis, C. paradisi, and $C$. limon) being propagated through grafting as well as the large areas cultivated with these Citrus spp. (16). Consequently, pathogens do not face a significant selection pressure due to the genetic homogeneity of the host. However, a new variant of $X$. citri, strain $\mathrm{A}^{\mathrm{T}}$, was differentially recognized according to the analyzed citrus host. Nevertheless, clustering analysis showed a genomic similarity $>90 \%$ of $X$. citri $\mathrm{A}^{\mathrm{T}}$ with 21 other $X$. citri strains, including the reference strain $X$. citri $\mathrm{T}$.

The new variant $X$. citri $\mathrm{A}^{\mathrm{T}}$ induces an atypical chlorotic phenotype in $C$. limon and $C$. paradisi. This host response is phenotypically different from the symptoms elicited by $X$. citri strain $\mathrm{A}^{\mathrm{w}}$ on $C$. paradisi leaves (42). In addition, $X$. citri strain $\mathrm{A}^{\mathrm{w}}$ is asymptomatic on $C$. limon and induces strong CBC symptoms on C. aurantifolia leaves (31). Furthermore, the reaction elicited by the variant $X$. citri $\mathrm{A}^{\mathrm{T}}$ in $C$. limon is phenotypically different from the canonical HR induced by the more distantly related $X$. aurantifolii strain $\mathrm{C}$ in this citrus host (3).

We have shown previously that xanthan plays a key role in biofilm formation, canker development, and suppression of defenses in C. limon $(13,29)$. The characterization of X. citri $\mathrm{A}^{\mathrm{T}}$ indicated that it produces 10 times less EPS than the reference strain $X$. citri $\mathrm{T}$. Therefore, we might hypothesize that this EPS deficiency of $X$. citri $\mathrm{A}^{\mathrm{T}}$ would be involved in the suppression of canker development shown on $C$. limon and $C$. paradisi leaves. However, the EPS level of this strain was sufficient to suppress PAMP-triggered immunity, leading to the development of cankerous lesions on $C$. aurantifolia and $C$. clementina leaves. In addition, the inoculation of $C$. limon with $X$. citri $\mathrm{A}^{\mathrm{T}}$ supplemented with exogenous xanthan did not restore its pathogenicity, as it did with the $X$. citri $\mathrm{MgumB}$ mutant, suggesting the activation of different defense signaling pathways able to contain the pathogen.

The presence of $\mathrm{H}_{2} \mathrm{O}_{2}$ is characteristic of plant tissues undergoing a programmed cell death (26), suggesting that the $\mathrm{H}_{2} \mathrm{O}_{2}$ accumulation shown in the $C$. limon-X. citri $\mathrm{A}^{\mathrm{T}}$ interaction actually could be a component of the host-specific defense response that suppresses disease development. However, further transcriptional and metabolomic analyses should be done to establish the signaling pathways involved in this resistance response.

Our results suggest the presence of Xanthomonas spp.-encoded factors involved in triggering host-specific resistance to $\mathrm{CBC}$ in C. limon. Although a high genetic similarity at the genomic level was detected between the reference strain $X$. citri $\mathrm{T}$ and the variant $A^{T}$, it cannot be excluded that differences at genomic or plasmid DNA level occur and account for the specific recognition of $X$. citri $\mathrm{A}^{\mathrm{T}}$ by $C$. limon and C. paradisi hosts. Even though no resistance genes to $X$. citri have been identified in Citrus spp., two avirulence gene products from the $X$. citri strain $\mathrm{A}^{\mathrm{w}}$ and $X$. aurantifolii strain $\mathrm{C}$ had been recently isolated $(1,31)$. On the other hand, it was demonstrated that pthA gene homologs allow intergenic recombinations, resulting in paralogs with specific pathogenicity according to the citrus host $(1,14,35,36)$. For this reason, a genome-wide analysis of the variant $X$. citri $\mathrm{A}^{\mathrm{T}}$ should advance our understanding of the adaptation of this bacterium to different citrus hosts.

\section{ACKNOWLEDGMENTS}

This work was supported by the Agencia Nacional de Promoción Científica y Tecnológica PICT-2007-00469 to M. R. Marano. M. A. Chiesa and M. F. Siciliano contributed equally to this work. M. A. Chiesa, M. P. Filippone, A. A. Vojnov, A. P. Castagnaro, and M. R. Marano are Career Investigators of the National Scientific and Technical Research Council (CONICET).We thank J. Ramallo of the Phytopathology Section of the Estación Experimental Agroindustrial Obispo Colombres, EEAOC, Tucumán, for providing the field isolates of CBC-causing Xanthomonas used in this work; Blanca Canteros of Instituto Nacional de Tecnología Agropecuaria, INTA, Bella Vista, Corrientes, for providing reference 
strains $X C 2525, X C 99-1330, X f a \mathrm{~B}$, and $X f a \mathrm{C}$; and M. Richey for critical review of the manuscript.

\section{LITERATURE CITED}

1. Al-Saadi, A., Reddy, J. D., Duan, Y. P., Brunings, A. M., Yuan, Q., and Gabriel, D. W. 2007. All five host-range variants of Xanthomonas citri carry one pthA homolog with 17.5 repeats that determines pathogenicity on citrus, but none determine host-range variation. Mol. Plant-Microbe Interact. 20:934-943.

2. Baptista, J. C., Machado, M. A., Homem, R. A., Torres, P. S., Vojnov, A. A., and Morais do Amaral, A. M. 2010. Mutation in the xpsD gene of Xanthomonas axonopodis pv. citri affects cellulose degradation and virulence. Genet. Mol. Biol. 33:146-153.

3. Brunings, A. M., and Gabriel, D. W. 2003. Xanthomonas citri: Breaking the surface. Mol. Plant Pathol. 4:141-157.

4. Bui Thi Ngoc, L. V. C., Jarne, P., Brisse, S., Guerin, F., Boutry, S., Gagnevin, L., and Pruvost, O. 2009. From local surveys to global surveillance: Three high-throughput genotyping methods for epidemiological monitoring of Xanthomonas citri pv. citri pathotypes. Appl. Environ. Microbiol. 75:1173-1184.

5. Buttner, D., and Bonas, U. 2010. Regulation and secretion of Xanthomonas virulence factors. FEMS Microbiol. Rev. 34:107-133.

6. Cadmus, M., Rojovin, S. P., Burton, K. A., Pittsley, J. E., Knutson, C. A., and Jeanes, A. 1976. Colonial variation in Xanthomonas campestris NRRL B-1459 and characterization of the polysaccharide from a variant strain. Can. J. Microbiol. 22:942-948.

7. Canteros, B. I. 2004. Management of Citrus canker in Argentina. A review. Abstr. No. 90. Xth Int. Citrus Congr., Agadir, Morocco.

8. Carvalho, F. M. S., Caramori, P. C. L., and Leite, R. P., Jr. 2005. Genetic diversity of Xanthomonas axonopodis pv. citri based on plasmid profile and pulsed field gel electrophoresis. Genet. Mol. Biol. 28:446-451.

9. Cernadas, R. A., Camillo, L. R., and Benedetti, C. E. 2008. Transcriptional analysis of the sweet orange interaction with the citrus canker pathogens Xanthomonas axonopodis pv. citri and Xanthomonas axonopodis pv. aurantifolii. Mol. Plant Pathol. 9:609-631.

10. Chen, W. P., and Kuo, T. T. 1993. A simple and rapid method for the preparation of gram-negative bacterial genomic DNA. Nucleic Acids Res. 21:2260.

11. Cubero, J., and Graham, J. H. 2002. Genetic relationship among worldwide strains of Xanthomonas causing canker in citrus species and design of new primers. Appl. Environ. Microbiol. 68:1257-1264.

12. da Silva, A. C., Ferro, J. A., Reinach, F. C., Farah, C. S., Furlan, L. R., Quaggio, R. B., Monteiro-Vitorello, C. B., Van Sluys, M. A., Almeida, N. F., Alves, L. M., do Amaral, A. M., Bertolini, M. C., Camargo, L. E., Camarotte, G., Cannavan, F., Cardozo, J., Chambergo, F., Ciapina, L. P., Cicarelli, R. M., Coutinho, L. L., Cursino-Santos, J. R., El-Dorry, H., Faria, J. B., Ferreira, A. J., Ferreira, R. C., Ferro, M. I., Formighieri, E. F., Franco, M. C., Greggio, C. C., Gruber, A., Katsuyama, A. M., Kishi, L. T., Leite, R. P., Lemos, E. G., Lemos, M. V., Locali, E. C., Machado, M. A., Madeira, A. M., Martinez-Rossi, N. M., Martins, E. C., Meidanis, J., Menck, C. F., Miyaki, C. Y., Moon, D. H., Moreira, L. M., Novo, M. T., Okura, V. K., Oliveira, M. C., Oliveira, V. R., Pereira, H. A., Rossi, A., Sena, J. A., Silva, C., de Souza, R. F., Spinola, L. A., Takita, M. A., Tamura, R. E., Teixeira, E. C., Tezza, R. I., Trindade, M., dos Santos, D., Truffi, D., Tsai, S. M., White, F. F., Setubal, J. C., and Kitajima, J. P. 2002. Comparison of the genomes of two Xanthomonas pathogens with differing host specificities. Nature 417:459-463.

13. Enrique, R., Siciliano, M. F., Favaro, M. A., Gerhardt, N., Roeschlin, R., Rigano, L., Sendin, L., Castagnaro, A., Vojnov, A., and Marano, M. R. 2011. Novel demonstration of RNAi in Citrus reveals importance of citrus callose synthase in defence against Xanthomonas citri ssp. citri. Plant Biotechnol. J. 9:394-407.

14. Fujikawa, T., Ishihara, H., Leach, J. E., and Tsuyumu, S. 2006. Suppression of defense response in plants by the avrBs3/pthA gene family of Xanthomonas spp. Mol. Plant-Microbe Interact. 19:342-349.

15. Gent, D. H., Al-Saadi, A., Gabriel, D. W., Louws, F. J., Ishimaru, C. A., and Schwartz, H. F. 2005. Pathogenic and genetic relatedness among Xanthomonas axonopodis pv. allii and other pathovars of $X$. axonopodis. Phytopathology 95:918-925.

16. Graham, J. H., Gottwald, T. R., Cubero, J., and Achor, D. S. 2004. Xanthomonas axonopodis pv. citri: Factors affecting successful eradication of citrus canker. Mol. Plant Pathol. 1:1-15.

17. Jaccard, P. 1908. Nouvelles recherches sur la distribution florale. Bull. Soc. Vaud. Sci. Nat. 44:223-270.

18. Kaczynski, Z., Braun, S., Lindner, B., Niehaus, K., and Holst, O. 2007. Investigation of the chemical structure and biological activity of oligosaccharides isolated from rough-type Xanthomonas campestris pv. campestris B100 lipopolysaccharide. J. Endotoxin Res. 13:101-108.
19. Khalaf, A., Moore, G. A., Jones, J. B., and Gmitter, F. G., Jr. 2007. New insights into the resistance of Nagami kumquat to canker disease. Physiol. Mol. Plant Pathol. 71:240-250.

20. Louws, F. J., Bell, J., Medina-Mora, C. M., Smart, C. D., and Opgenorth, D. 1998. Rep-PCR mediated genomic fingerprinting: A rapid and effective method to identify Clavibacter michiganensis. Phytopathology 88:862-868.

21. Louws, F. J., Fulbright, D. W., Stephens, C. T., and de Bruijn, F. J. 1994. Specific genomic fingerprints of phytopathogenic Xanthomonas and Pseudomonas pathovars and strains generated with repetitive sequences and PCR. Appl. Environ. Microbiol. 60:2286-2295.

22. Malamud, F., Conforte, V. P., Rigano, L. A., Castagnaro, A. P., Marano, M. R., Morais do Amaral, A., and Vojnov, A. A. 2012. HrpM is involved in glucan biosynthesis, biofilm formation and pathogenicity in Xanthomonas citri ssp. citri. Mol. Plant Pathol. Online publication. doi:10.1111/ j.1364-3703.2012.00809

23. Mondal, K. K., and Mani, C. 2009. ERIC-PCR-generated genomic fingerprints and their relationship with pathogenic variability of Xanthomonas campestris pv. punicae, the incitant of bacterial blight of pomegranate. Curr. Microbiol. 59:616-620.

24. Moreira, L. M., Almeida, N. F., Jr., Potnis, N., Digiampietri, L. A., Adi, S. S., Bortolossi, J. C., da Silva, A. C., da Silva, A. M., de Moraes, F. E., de Oliveira, J. C., de Souza R. F., Facincani, A. P., Ferraz, A. L., Ferro, M. I., Furlan, L. R., Gimenez, D. F., Jones, J. B., Kitajima, E. W., Laia, M. L., Leite, R. P., Jr., Nishiyama, M. Y., Rodrigues Neto, J., Nociti, L. A., Norman, D. J., Ostroski, E. H., Pereira, H. A., Jr., Staskawicz, B. J., Tezza, R. I., Ferro, J. A., Vinatzer, B. A., and Setubal, J. C. 2010. Novel insights into the genomic basis of citrus canker based on the genome sequences of two strains of Xanthomonas fuscans ssp. aurantifolii. BMC Genomics 1:238.

25. Peakall, R., and Smouse, P. E. 2006. GenAlEx 6: Genetic analysis in Excel. Population genetic software for teaching and research. Mol. Ecol. Notes 6:288-295.

26. Quan, L. J., Zhang, B., Shi, W. W., and Li, H. Y. 2008. Hydrogen peroxide in plants: A versatile molecule of the reactive oxygen species network. J. Integr. Plant Biol. 50:2-18.

27. Rademaker, J. L., Louws, F. J., Schultz, M. H., Rossbach, U., Vauterin, L., Swings, J., and de Bruijn, F. J. 2005. A comprehensive species to strain taxonomic framework for Xanthomonas. Phytopathology 95:1098-1111.

28. Rigano, L. A., Marano, M. R., Castagnaro, A. P., Morais Do Amaral, A., and Vojnov, A. A. 2010. Rapid and sensitive detection of Citrus Bacterial Canker by loop-mediated isothermal amplification combined with simple visual evaluation methods. BMC Microbiol. 10:176-184.

29. Rigano, L. A., Siciliano, F., Enrique, R., Sendin, L., Filippone, P., Torres, P. S., Questa, J., Dow, J. M., Castagnaro, A. P., Vojnov, A. A., and Marano, M. R. 2007. Biofilm formation, epiphytic fitness, and canker development in Xanthomonas axonopodis pv. citri. Mol. Plant-Microbe. Interact. 20:1222-1230.

30. Rohlf, F. J. 1997. NTSYS-pc, version 2.01. Exeter Software, Setauket, NY.

31. Rybak, M., Minsavage, G. V., Stall, R. E., and Jones, J. B. 2009. Identification of Xanthomonas citri ssp. citri host specificity genes in a heterologous expression host. Mol. Plant Pathol. 10:249-262.

32. Sambrook, J., Fritschm, E. F., and Maniatis, T. 1989. Molecular Cloning: A Laboratory Manual, 2nd ed., Cold Spring Harbor Laboratory Press, Cold Spring Harbor, NY.

33. Schaad, N. C., Postnikova, E., Lacy, G. H., Sechler, A., Agarkova, I., Stromberg, P. E., Stromberg, V. K., and Vidaver, A. K. 2006. Emended classification of xanthomonad pathogens on citrus. Syst. Appl. Microbiol. 29:690-695

34. Schaad, N. W., Postnikova, E., Lacy, G. H., Sechler, A., Agarkova, I., Stromberg, P. E., Stromberg, V. K., and Vidaver, A. K. 2005. Reclassification of Xanthomonas campestris pv. citri (ex Hasse 1915) Dye 1978 forms A, B/C/D, and E as X. smithii ssp. citri (ex Hasse) sp. nov. nom. rev. comb. nov., X. fuscans ssp. aurantifolii (ex Gabriel 1989) sp. nov. nom. rev. comb. nov., and X. alfalfae ssp. citrumelo (ex Riker and Jones) Gabriel et al., 1989 sp. nov. nom. rev. comb. nov.; X. campestris pv. malvacearum (ex smith 1901) Dye 1978 as X. smithii ssp. smithii nov. comb. nov. nom. nov.; X. campestris pv. alfalfae (ex Riker and Jones, 1935) dye 1978 as X. alfalfae ssp. alfalfae (ex Riker et al., 1935) sp. nov. nom. rev.; and "var. fuscans" of $X$. campestris pv. phaseoli (ex Smith, 1987) Dye 1978 as X. fuscans ssp. fuscans sp. nov. Syst. Appl. Microbiol. 28:494-518.

35. Shiotani, H., Fujikawa, F., Ishiihara, H., Tsuyumu, S., and Ozaki, K. 2007. A pthA homolog from Xanthomonas axonopodis pv. citri responsible for host-specific suppression of virulence. J. Bacteriol. 189:32713279.

36. Shiotani, H. Y. T., Yamamoto, M., and Matsumoto, R. 2008. Susceptibility to citrus canker caused by Xanthomonas axonopodis pv. citri depends on the nuclear genome of the host plant. J. Gen. Plant Pathol. 74:133-137. 
37. Siciliano, F., Torres, P., Sendin, L., Bermejo, C., Filippone, P., Vellice, G., Ramallo, J., Castagnaro, A. P., Vojnov, A. A., and Marano, M. R. 2006. Analysis of the molecular basis of Xanthomonas axonopodis pv. citri pathogenesis in Citrus limon. Electron. J. Biotechnol. 9:199-204.

38. Smouse, P. E., Long, J. C., and Sokal, R. R. 1986. Multiple regression and correlation extensions of the Mantel test of matrix correspondence. Syst. Zool. 35:627-632.

39. Stein, B., Ramallo, J., Foguet, L., and Graham, J. H. 2007. Citrus leafminer control and copper spray for management of citrus canker on lemon in Tucumán, Argentina. Proc. Fla. State Hortic. Soc. 120:127-131.

40. Swarup, S., De Feyter, R., Brlansky, R. H., and Gabriel, D. W. 1991. A pathogenicity locus from Xanthomonas citri enables strains from several pathovars of $X$. campestris to elicit canker-like lesions on citrus. Phytopathology 81:802-809.

41. Swarup, S., Yang, Y., Kingsley, M. T., and Gabriel, D. W. 1992. A Xanthomonas citri pathogenicity gene, $p t h A$, pleiotropically encodes gratui- tous avirulence on nonhosts. Mol. Plant-Microbe Interact. 5:204-213.

42. Verniere, C., Hartung, J. S., Pruvost, O. P., Civerolo, E. L., Alvarez, A. M., Maestri, P., and Luisetti, J. 1998. Characterization of phenotypically distinct strains of Xanthomonas axonopodis pv. citri from Southwest Asia. Eur. J. Plant Pathol. 104:477-487.

43. Vojnov, A. A., Zorreguieta, A., Dow, J. M., Daniels, M. J., and Dankert, M. A. 1998. Evidence for a role for the gumB and gumC gene products in the formation of xanthan from its pentasaccharide repeating unit by Xanthomonas campestris. Microbiology 144:1487-1493.

44. Yang, Y., and Gabriel, D. W. 1995. Intragenic recombination of a single plant pathogen gene provides a mechanism for the evolution of new host specificities. J. Bacteriol. 177:4963-4968.

45. Yap, I. V., and Nielsen, R. J. 1996. WinBoot: A program for performing bootstrap analysis of binary data to determine the confidence limits of UPGMA-based dendrograms. Disc Ser. No. 14. IRRI Int. Rice Res. Inst. Manila, Philippines. 